\title{
Local perspective, aspiration and women empowerment in housing development in Africa: Nigeria
}

\author{
Raimi A. Asiyanbola \\ Department of Geography and Regional Planning, Olabisi Onabanjo University, Ago-Iwoye, Ogun State, \\ Nigeria, \\ Paper submitted for presentation at the First International Conference on Society, Technology and Sustainable \\ Development organized by the Department of Social Work, Amrita Vishwa Vidyapeetham, Amritapuri Campus \\ and School of Social Work, the University at Buffalo, State University of NewYork held at the Amrita Institute of \\ Medical Sciences, Kochi, India on June 3-5, 2011
}

\begin{abstract}
The paper examines the local perspective on the involvement aspiration of women in housing development in Ibadan, Nigeria. The aim of the paper is twofold. The first aim is an examination of the local perspective about women's involvement in housing development. The second aim is an examination of the influence of local perspective on housing development involvement aspiration of women as indicated by the actual housing development involvement of women, women's level of knowledge about the development of their household house, and women's intension to be involved in housing delivery. The null hypotheses tested in the paper is that there is no significant relationship between the local perspective about women's involvement in housing development and (i) actual housing development involvement of women, (ii) women's level of knowledge about the development of their household house, and (iii) women's intension to be involved in housing delivery. The data used in the paper were derived from a larger household survey on gender and housing study carried out by the author in Ibadan, Nigeria. Correlation statistical technique was used to test the hypotheses. The literature shows that the local perspective is that decisions on housing development are male dominated. Significant negative relationship is found between local perspective and (i) actual housing development involvement of women, (ii) women's level of knowledge about the development of their household house, and, (iii) women's intention to be involved in housing delivery. This result suggests that women empowerment could be greatly enhanced through a reorientation of the mindset of the society about some of the local perspective that hinders women's involvement in development activities.
\end{abstract}

Keywords: Local perspective; aspiration; women empowerment; housing development.

\section{Introduction}

Housing is universally acknowledged as one of the most basic human needs with a profound impact on general well-being. According to the definition given by the World Health Organization (WHO), housing is a residential environment that includes the physical structure that man uses for shelter, all necessary services, facilities, equipment, and devices needed or desired for the physical and mental health and social well-being of the family and individual. It is therefore critical for the achievement of health for all, employment, social stability and economic development. As a prerequisite for survival, housing only ranks second to food (Onibokun, 1985; Adeniyi, 1985). It is also one of the indicators of a person's standard of living and of his place in society. Housing reflects the cultural, social and economic values of a society as it is the best physical and historical evidence of civilization in a country (Onibokun, 1985).

Housing encompasses far more than living space and shelter (Knox, 1992). Its nature and value are determined by its varied services, which include neighbourhood amenities, access to education, health facilities and security, in addition to shelter. The worth of housing depends upon quality consideration, such as design, density, building materials and floor spaces and on access to employment and other income earning opportunities, public facilities, community services and market. Housing is a durable good unlike most consumer goods. It is a fixed location asset and it constitutes the largest space user in the city and has played a major role in shaping urban regions (Harthorn, 1992).

In recent years, various countries of the world and different international bodies have recognized the significance of the involvement of women in development and have devoted considerable attention to women's contribution to economic progress. These countries and organizations have emphasized the need to actively involve women in the design and implementation of various development programmes so as to make them more active and effective participants in the socio-economic cum cultural activities of their countries and/or associations (Agbola, 1990a; 1990b; Moser, 1992, 1993; Young, 1995; UNCHS, 1996; etc).

Although there has been increased focus on the actual and potential involvement of women in development generally and with special emphasis on agriculture and the industry, only in recent times has there 
been an interest in their housing situation (Agbola, 1990a). Various scholars have asserted that women, as the major consumers and users of shelter and infrastructure, must not only be consulted at every turn of the housing development process, they should actively participate (Agbola, 1990b). Observation from the literature shows that in both theory and practice this has not been the case, particularly with respect to women's participation in the built environment (Peterson et al, 1978; Cater and Trevor, 1989; Agbola, 1990a; Short, 1996; Johnston, 1998; Amole, 1998; Olatubara, 2003). In feminist geography one of the three main themes identified in the early work is patriarchal power, which illustrated the 'blindness' of (urban and other) geographers to the 'embodiment of conventional gender divisions' in the built environment on both large (the structuring of urban land-use patterns) and small (the design and layout of buildings) scales (Cater and Trevor, 1989; Short, 1996; Johnston, 1998). Cater and Trevor (1989) argues that this is no accident but the logical outcome of male power and female powerlessness - all the crucial decisions about the built structures of cities and regions were and are still being taken by males and they have constructed man-oriented geographic space. Even where women have been included in the calculations, this has been women as seen through men's eyes; women's needs as defined by men and not by women themselves (Cater and Trevor, 1989). Peterson et al (1978) have taken environmental scale or setting as a starting point and examined the degree of control exerted by women and men over environmental settings at different points on the scale. They consider environments ranging from the "home" to the "world" and relate this to the spheres in which women and men are concentrated. It becomes clear that men are dominant (in a control sense) at the scale of the "world", city, and region by virtue of their political, economic, and employment roles. Women, on the other hand, tend to occupy spaces at the home and neighbourhood levels. Peterson et al (1978) notes that despite women's numerical concentration at the home and neighbourhood scales, key decisions about these spheres tend to be made by institutions operating at the citywide, regional, or national scales and few women penetrate into these spheres, particularly in positions of power. In a review of the effect of design on women, Hayden and Wright (1976) have noted that women have been most closely associated with domestic environments, but almost always as passive clients. They have had to accept spatial and social traditions that confine to certain kinds of structures, and they have had to transform their homes and lives according to the changing standards of advertising, zoning legislation, welfare policy, or neighbourhood pressure for conformity (Hayden and Wright, 1976).

The focus of professionals engaged in the business of creating dwellings and dwelling environments has been on households defined and interpreted more often as household heads, whereas women are the primary and major consumers and users of these environments. For instance, it is common for the architect, in preparing a programme of requirements for the design of owner-occupied residences, to involve in the process, only the household head (usually a man) who has commissioned him to design a house. Little or no importance is attached to the specific requirements, values, roles and attitudes of women with respect to both the dwelling and its environment (Amole, 1998).

\section{Local Perspective On Women Involvement In Housing Development}

In Nigeria, patriarchy structure has been a major feature of the traditional society (Aina 1998). It is a structure of a set of social relations with material base which enables men to dominate women (Stacey 1993; Kramarae 1992; Lerner 1986; Humm 1989; Aina 1998). It is a system of social stratification and differentiation on the basis of sex, which provides material advantages to males while simultaneously placing severe constraints on the roles and activities of females. There are clearly defined sex roles, while various taboos ensure conformity with specified gender roles (Aina 1998). Traditionally men do not participate in domestic work including child rearing - such tasks are considered to be the exclusive domain of women. Males are classed as having the following qualities: strength, vigor, virile/powerful courage, self-confidence and the ability to meet the outside world i.e. animal and human intruders head on and deal with it effectively. These qualities were reflected in the kinds of work that men engaged in. Men were responsible for much of what was thought of as "heavy" labour. Men in short provided for their families (Bernard 1981; Aweda 1984; Carrigan et al, 1987; Stock 1995; Silberschmidt, 1999 etc.). Women oversee the domestic chores. They kept houses, processed and cooked all foods. They also help in the planting and harvesting of food crops and cash crops. They were primarily responsible for the bearing and rearing of children from birth on; men were only called upon to assist when extraordinary discipline was considered necessary especially for the boys (Aweda, 1984).

Empirical evidence on women's actual experience of housing is rare in Nigeria. As Agbola (1990a) and Asiyanbola (1997) notes, there has been little contribution of researches on women's housing situation. Most of the available literatures on this issue are works carried out in developed countries. As observed by Wood (1994), most of such studies while addressing a wide range of issues with regard to women and housing, have focused on women and the meaning of house, economic constraints, weakness in the law relating to family breakdown and inadequacies in homeless persons' legislation, general problems of allocation systems, housing concerns of specific groups of women, education, training and employment issues, gender roles and the form of the built 
environment. Of importance here are planning policies, architecture and design. These are argued to be gender blind (Wood, 1994).

An exception to the research orientation common in the developing countries is Agbola's work (1990b) and Olatubara's work (2003) in which they examined the role of women in housing development and women participation in residential location decision-making respectively in Ibadan, Oyo State, Nigeria. Agbola (1990b) observes that most women living with their husbands show alarming disinterestedness in the land acquisition process and contribute relatively minimally to the finance of the building. Women-headed households shouldered the whole responsibility themselves at all stages of the housing development process. He also observes that women professionals are few and those living with their husbands assist their husbands in land acquisition and finance. Women on construction sites are found to be mostly uneducated, earns very low income which is often used for food to feed the family. He observes that women are more involved in housing maintenance than in any other housing development activities. He notes further that top on the list of problems inhibiting women's participation in the housing development was male dominance, followed by poverty, lack of concern and illiteracy respectively (Agbola, 1990). Olatubara's work examines the level of women's participation in the choice of where the household resides in the urban centre and which house is selected as well as the association between decision-making on choice of residential district and age of the respondent, rent contribution by respondent, position of wife, availability of vehicle in the household, residential density and income of respondent. His findings shows male dominance in decision-making, significant joint decision between husband and wife and the economic status of the women as an important factor that makes them to participate more or less in residential location decision (Olatubara, 2003).

Findings from the study from which the data for this paper is derived have shown among others that there is low involvement of women in housing development; the general perception of women is that housing provisions are the responsibilities of male head of households; building activities are viewed more as men's job; men are found to have applied more for building plan registration and certificates of occupancy than women; men are found to own more plots of land, more number of houses and housing plots than women (Asiyanbola and Filani, 2007; 2008a; 2008b). Thus as shown in the literature, the local perspective is that male head of household dominate decisions on critical aspects of housing development.

The second aim of the paper is to examine the influence of local perspective on housing development involvement aspiration of women as indicated by the actual housing development involvement of women, women's level of knowledge about the development of their household house, and women's intension to be involved in housing delivery. This aim builds on the existing works by providing insight on the influence of local perception on the housing development involvement aspiration of women in Nigeria. The importance of this aim lies in the fact that in sociological and psychological tradition there has been a widespread acceptance of the assumption that there is a close correspondence between the ways in which a person behaves towards some object and his/her (sic) beliefs, feelings and intentions with respect to that object (Fishbein and Ajzen, 1975:336). Indeed, Allport (1968) attributes to Plato the idea that the mind is constituted of, and human action determined by, the three faculties of affection (feeling), conation (striving) and cognition (thought). Although the relationship between some attitudes and expected behaviour has proved to be less than ideal, "the best single predictor of an individual's behaviour will be a measure of his (sic) beliefs, feelings and intention to perform that behaviour (Fishbein and Ajzen, 1975; Merlo and McDonald, 2002). It is in these traditions that the study seeks to examine the influence of the local perspective as reflected by the general beliefs and feelings about women's involvement in housing development on actual housing development involvement of women, women's level of knowledge about the development of their household house and women's intension to be involved in housing delivery. The null hypotheses tested in the paper is that there is no significant relationship between the local perspective on women's involvement in housing development and (i) actual housing development involvement of women, (ii) women's level of knowledge about the development of their household house, and (iii) women's intension to be involved in housing delivery.

Ibadan city, which is the case study, is located in the South-western part of Nigeria. The total population size of the wider Ibadan region was 1,258,625 according to the 1963 census and 1,991,367 in 1991 out of which 988,923 are male while 1,002,444 are female (Afolayan, 1994). The city was for a long time the largest city in tropical Africa. Although, it has now been surpassed by Lagos, it remains a truly Nigerian city. By virtue of its historical, political, administrative, cultural and socio-economic importance over the years, there is hardly any major ethnic or sub-ethnic group in Nigeria that is not represented in this city (Mabogunje 1968; Filani et al 1994). Thus any study undertaken in the city can mirror what happens to women of diverse ethnic origin in Nigeria. It is important to note that the literature on this important city is ever expanding representing different academic and research interests (see, Filani et al 1994). 


\section{Method Of Data Collection And Analysis}

Data used in the paper were obtained from a cross-sectional survey of 721 households in Ibadan, Oyo State, Nigeria. The survey was undertaken between November 1999 and March 2001. The sampling frame utilized was the total number of estimated households in Ibadan municipal area as of 1999. The average household size declared for Nigeria in the result of the National Population Commission (NPC) 1995/96 household survey is 4.48 . This was used to divide the projected 1999 population of each locality as defined by the National Population Commission (NPC) in the Ibadan municipal area to get an estimate of the number of households. To make for effective and objective coverage, due to non availability of the list of all households in each locality in Ibadan, the number of questionnaires administered in each locality was proportional to the total number of estimated households in each locality. For the purpose of intra-urban analysis, each of the locality in Ibadan municipal area as defined by the National Population Commission (NPC) was accordingly sorted into four residential areas - high density residential area (comprising traditional core high density residential area of Ibadan and non-traditional core high density residential area), medium density residential area and low density residential area - according to where it was located following existing studies on Ibadan metropolis (Mabogunje, 1962, 1968; NISER, 1988; Ayeni, 1982; 1994; Filani et al, 1994; Abumere, 1994). For example, the traditional core high density or indigenous areas of Ibadan correspond roughly with Mabogunje's (1962) core and older suburbs and Ayeni's (1982) high density residential areas. Also the non-traditional core high density residential areas roughly correspond with NISER's (1988) new unplanned fringe and part of Ayeni's high density. The medium density roughly corresponds with Ayeni's (1982) classification of medium density residential areas and Mabogubje's (1962) newer eastern and western suburbs as well as post 1952 developments and NISER's (1988) intermediate zone. Both non-traditional core high density and medium density residential areas correspond with Abumere's (1994) zone of market forces. The low density residential areas correspond with Ayeni's (1982) classification of low density residential areas, Mabogunje's (1962) Bodija/Reservation and Estates, NISER's (1988) zone of planned settlement and Abumere's (1994) government zone or institutional zone (see Fig. I).

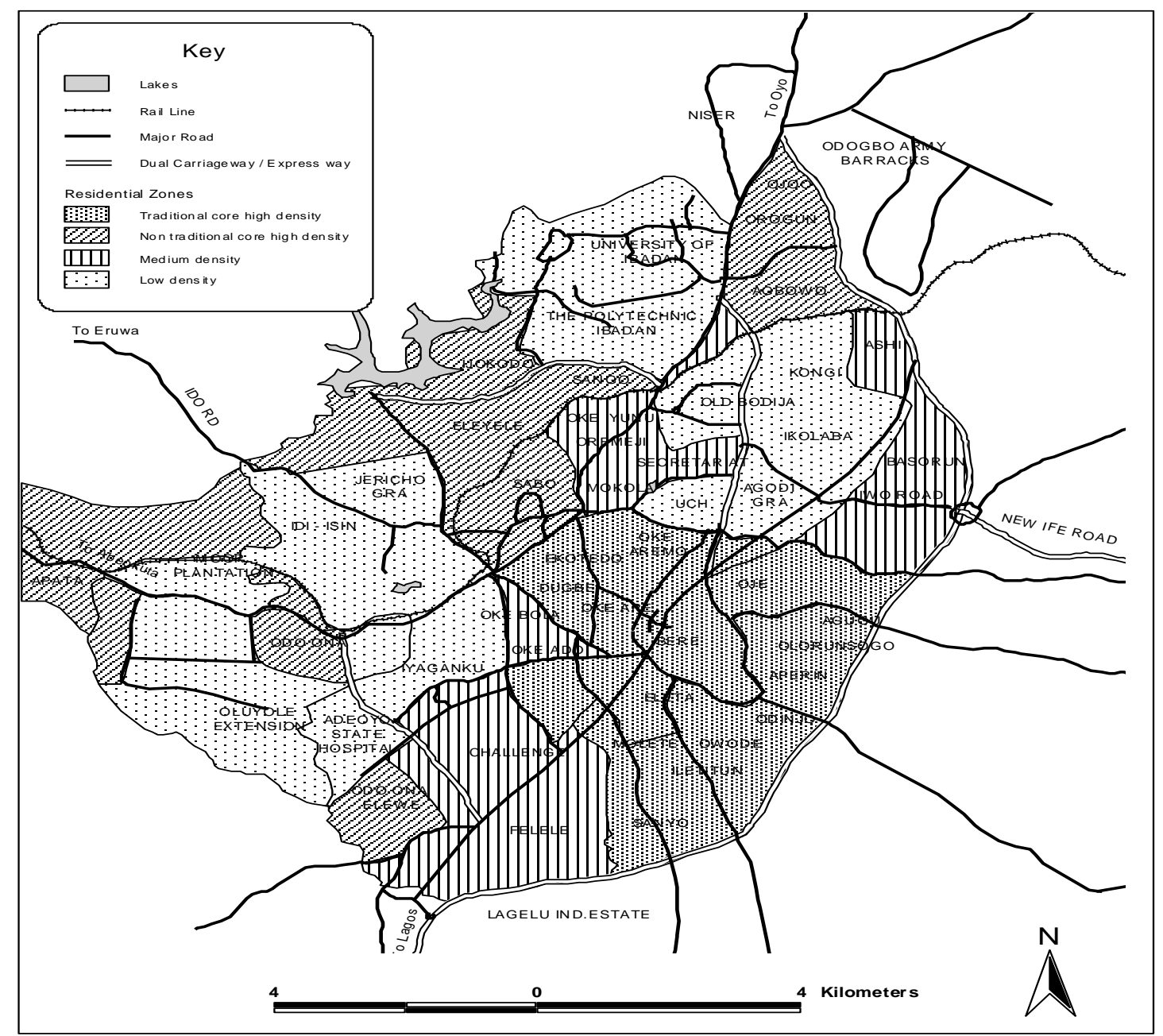

Fig. I: Ibadan showing residential density areas

Source: Adapted from Mabogunje (1962); NISER (1988); Ayeni (1982; 1994); Abumere (1994) 
The classification of high density into two - traditional core and non-traditional core - was based on the observation that these two residential areas which are usually classified together in Ibadan are distinct in social and physical patterns. This was observed from the literature, reconnaissance survey and consultation with town planners. In terms of socio-economic status and housing condition non-traditional core high density residential areas are better off. Also, in terms of ethnic status, traditional core areas are relatively homogeneous in the sense that majority of the residents are indigenes of Ibadan. In the non-traditional core high-density residential areas, residents are of different ethnic background.

The sampling procedure adopted was that of sampling along the major streets in each locality in which systematic random sampling was used in the selection of houses. From each selected houses, a household, particularly a woman and her spouse (if any) were interviewed. Information was collected on the general beliefs and feelings about the relative involvement of women and men in housing development, women's actual involvement, women's level of awareness of the development of their household house, and women's intention to be involved in housing delivery. Correlation statistics was used to test the hypotheses.

\subsection{Dependent variable - Local perspective (General beliefs and feelings about the relative involvement of women and men in housing development)}

Three variables are used to indicate the local perspective, that is, general beliefs and feelings about the involvement of women in housing development. Traditionally, male head of households are responsible for providing for their households. Thus, the first indicator is the view of household housing provision as male head of household responsibility. The responses are: men only, women only, men and women equally, women partially, women rarely, and women never. A code of 1 is assigned where men only are involved; otherwise a code of 0 is assigned. Again, males are classed as having the following qualities: strength, vigor, virile/powerful courage, self-confidence and the ability to meet the outside world i.e. animal and human intruders head on and deal with it effectively. These qualities were reflected in the kinds of work that men engaged in. Men were responsible for much of what was thought of as 'heavy' labour. Building activities job involves 'heavy' labour, thus, the second indicator is the view of building activities job as male job. The responses are: wholly men's job, wholly women's job, or partially women's job. A code of 1 is assigned if wholly men's job, otherwise a code of 0 is assigned. As stated previously, the Nigerian society is patriarchal - a structure of a set of social relations with material base which enables men to dominate women. As such, the third variable is an indicator of male dominance in decision-making - the view that men majorly are involved in decisions on each of the critical aspects of household housing development that have been identified in the literature (Agbola, 1990b): land acquisition and preparation, housing design and planning, housing development finance, building material production/procurement, housing construction, and housing maintenance which comprises housing structural defects repairs, housing non-structural repairs, housing preventive maintenance, housing improvement and housing modernization. Respondents were asked to state from their perception and knowledge of their culture the involvement of women/men in various critical aspects of housing development decisions. The responses are: men only, women only, men and women equally, women partially, women rarely, and women never. A code of 1 is assigned where men only are involved; otherwise a code of 0 is assigned.

\subsection{Independent variables}

\subsubsection{Women's actual involvement in housing development}

Three variables are used to indicate women's actual involvement in housing development. The first and second variables are the actual number of plots of land and houses owned by women respectively. In each case, women respondents were asked to state the number of plots of land and houses owned. The third variable is a measure of the actual involvement of women in the development of the various critical aspects of the house owned and occupied by their households. In this case, women respondents were asked to state whether they are: wholly involved, partially involved, or not involved in the development of the following critical aspects of house owned and occupied by their households: land acquisition and preparation, housing design and planning, housing development finance, building material production/procurement, housing construction, and housing maintenance which comprises housing structural defects repairs, housing non-structural repairs, housing preventive maintenance, housing improvement and housing modernization. A code of 1 is assigned where women are wholly involved or partially involved otherwise a code of 0 is assigned.

\subsubsection{Women's awareness/knowledge of the development of the various critical aspects of the house owned and occupied by their households}

On women's awareness/knowledge of the development of the various critical aspects of the house owned and occupied by their households, women respondents were asked to state whether they are aware or not aware of the following critical aspects of housing development: land acquisition and preparation, housing design and planning, housing development finance, building material production/procurement, housing construction, 
and housing maintenance which comprises housing structural defects repairs, housing non-structural repairs, housing preventive maintenance, housing improvement and housing modernization.. A code of 1 is assigned where women are aware otherwise a code of 0 is assigned.

\subsubsection{Women's intention to be involved in housing development}

Three variables are used to indicate women's intention to be involved in housing development. The first variable is women's desire to own a house. In this case women respondents were asked if they want to own a house. The response is coded in binary form. A code of 1 is assigned where a woman want to own a house otherwise a code of 0 is assigned. The second variable is women's willingness to build a house alone. The response is coded in binary form. A code of 1 is assigned where a woman is willing to build a house alone otherwise a code of 0 is assigned. The third variable is the ability of women to build a house alone. The response is coded in binary form. A code of 1 is assigned where a woman says she is able to build a house alone otherwise a code of 0 is assigned. Table 1 shows the definition of variables used in the analysis.

Table 1: Definition of the variables used analysis

\begin{tabular}{|c|c|c|}
\hline $\mathrm{S} / \mathrm{N}$ & Variables & How Measured \\
\hline \multirow[t]{2}{*}{$\mathrm{A}$} & $\begin{array}{l}\text { Dependent Variable } \\
\text { (Y) }\end{array}$ & \\
\hline & $\begin{array}{l}\text { Local perspective } \\
\text { (General beliefs and } \\
\text { feelings about the } \\
\text { relative involvement of } \\
\text { women and men in } \\
\text { housing development) }\end{array}$ & $\begin{array}{l}\text {-1 if household housing provision is the sole responsibility of men. } \\
\text {-1 if building activities are wholly men's jobs } \\
\text { - } 1 \text { each if perceived that men majorly are involved in the decisions on: } \\
\text { (i) Land acquisition and preparation. } \\
\text { (ii) Housing planning and design } \\
\text { (iii) Finance of the building. } \\
\text { (iv) Procurement production of building materials } \\
\text { (v) Actual construction of building. } \\
\text { (vi) Housing maintenance }\end{array}$ \\
\hline \multirow[t]{4}{*}{$\overline{\mathrm{B}}$} & $\begin{array}{l}\text { Independent Variables } \\
(\mathrm{X})\end{array}$ & \\
\hline & $\begin{array}{l}\text { Women's actual } \\
\text { involvement in housing } \\
\text { development }\end{array}$ & $\begin{array}{l}\text { - Total number of plots of land owned. } \\
\text { - Number of houses owned. } \\
\text { - leach if women are wholly or partially involved in the development of } \\
\text { the following critical aspects of the house owned and occupied by their } \\
\text { household: } \\
\text { (i) Land acquisition and preparation. } \\
\text { (ii) Housing planning and design. } \\
\text { (iii) Finance of building. } \\
\text { (iv) Procurement production of building materials. } \\
\text { (v) Actual construction of building. } \\
\text { (vi) Housingmaintenance. }\end{array}$ \\
\hline & $\begin{array}{l}\text { Women's level of } \\
\text { awareness about the } \\
\text { critical aspect of } \\
\text { household housing } \\
\text { development }\end{array}$ & $\begin{array}{l}\text { I each if women is aware of development of the following critical } \\
\text { aspects of the house owned and occupied by their household: } \\
\text { (i) L and acquisition and preparation. } \\
\text { (ii) Housing planning and design } \\
\text { (iii) Finance of the building. } \\
\text { (iv) Procurement production of building materials } \\
\text { (v) Actual construction of building. } \\
\text { (vi) Housing maintenance }\end{array}$ \\
\hline & $\begin{array}{l}\text { Women's intention to be } \\
\text { involved in housing } \\
\text { delivery }\end{array}$ & $\begin{array}{l}\text { I if women want to own a house; } \\
1 \text { if women is willing to build a house alone } \\
1 \text { if women is able to build a house alone }\end{array}$ \\
\hline
\end{tabular}

\section{Influence of Local Perception on the Housing Development Involvement Aspiration of Women}

Table 2 shows the result of the correlation analysis between the local perspective on the involvement of women in housing development and women's actual involvement and level of knowledge about the critical aspects of their household housing development, as well as women's intention to be involved in housing delivery. 
Table 2: Result of the correlation analysis

\begin{tabular}{|c|c|c|}
\hline \multirow[t]{2}{*}{ Variables } & \multicolumn{2}{|c|}{$\begin{array}{l}\text { Local perspective on the involvement of women in housing } \\
\text { development }\end{array}$} \\
\hline & Correlation value $\left({ }^{6} \mathrm{r}^{3}\right)$ & Sig. value \\
\hline $\begin{array}{l}\text { Housing development } \\
\text { involvement of women }\end{array}$ & $-.269^{88}$ & .000 \\
\hline $\begin{array}{l}\text { Women's level of knowledge } \\
\text { about the critical aspects of } \\
\text { housing development }\end{array}$ & $-.184^{88}$ & .000 \\
\hline $\begin{array}{l}\text { Women's intention to be involved } \\
\text { in housing delivery }\end{array}$ & $-.093^{*}$ & .05 \\
\hline
\end{tabular}

* Significant at $p<.01$

$*$ Significant at $p<.05$

The table shows that there is a significant relationship between the local perspective and women's actual involvement and level of knowledge about the critical aspects of their household housing development, as well as women's intention to be involved in housing delivery. The result shows a negative relationship between the local perspective about the involvement of women in housing development and women's actual involvement in the development of their household house (-.269), women's level of knowledge about the critical aspects of their household housing development (-.184), and women's intention to be involved in housing delivery (-.093). This result implies that as long as the society holds onto the traditional beliefs about the involvement of women in housing development, the fewer will be the involvement of women in housing development.

\section{Conclusion}

The paper examines the local perspective on the housing development involvement aspiration of women in Ibadan, Nigeria. The literature shows that the local perspective is that decisions on housing development are male dominated. The correlation analysis result shows significant negative relationship between local perspective and (i) actual housing development involvement of women, (ii) women's level of knowledge about the development of their household house, and, (iii) women's intention to be involved in housing delivery. The study suggests that women's aspirations to be involved in development activities could be greatly enhanced through a reorientation of the mindset of the society about some of the local perspectives that hinder women's involvement in development activities. This could be achieved through gender education, enlightenment, awareness and consciousness raising of the society.

\section{Acknowledgement:}

The author is grateful to Council for the Development of Economic and Social Research in Africa (CODESRIA) for providing small grant for thesis writing for the $\mathrm{PhD}$ research project from which the data for this paper is derived.

\section{References:}

[1] Abumere S. I. (1994) "Residential differentiation in Ibadan: Some sketches of an explanation" in Filan M. O.; Akintola F. O.; and Ikporukpo C. O. (eds.) Ibadan Region Rex Charles Publication Ibadan, pp. 72-84

[2] Adeniyi,E.O. (1985) "Housing in Nigerian National Development" In Onibokun Poju (ed.) Housing in Nigeria: (A book of reading), NISER, Ibadan, pp. 91-104.

[3] Afolayan, A.A. (1976) Behavioural approach to the study of migration into, and mobility within the metropolitan Lagos. (Unpublished Phd thesis, Department of Geography, University of Ibadan, Ibadan)

[4] Agbola, T. (1986). "The Nature of Housing Subsidies in Nigeria". Journal of the Nigerian Institute of Town Planners, Vol. Vi and vii, December, pp. 86-98.

[5] Agbola, (1990a) The Role of Women in Housing Development. (Centre for Urban and Regional Planning, Faculty of Social Sciences, University of Ibadan, Ibadan).

[6] Agbola T. (1990b) "The Nature of women's Involvement in Housing Development: A survey of the Literature". African Urban Quarterly Vol. 5, Nos. 3 and 4, pp. 178-185.

[7] Agbola, T. (1998) The Housing of Nigerians: A Review of Policy Development and Implimentation. Research Report, No. 14, Development Policy Centre, Ibadan, Nigeria.

[8] Aina, Olabisi I. (1998) "Women, Culture and Society" in Amadu Sesay and Adetanwa Odebiyi (eds.) Nigerian Women in Society and Development. Dokun Publishing House, Ibadan, pp. 3-32.

[9] Allport, G. W. (1968) "The historical background of modern social psychology". In G. Lindzey and E. Aronson (eds) The handbook of social psychology, second edition. Addison-Wesley Publishing Company: Reading, Massachusetts.

[10] Amole Dolapo (1998) "Planned residential environments in Nigeria; implications for women" in

[11] Amole Bayo (ed.) Habitat studies in Nigeria: some qualitative dimensions. Shaneson, Ibadan, pp. 79-91

[12] Asiyanbola R. A. and Filani M. O. (2008a) "Gender and involvement in housing development in Ibadan, Nigeria" Gender and Behaviour (Published by The Ife Centre for Psychological Studies, Ile-Ife, Nigeria) Vol. 6, No. 2. pp. 1982-2007 
[13] Asiyanbola R. A. and Filani M. O. (2008b) "Gender and house ownership in Africa - Nigeria: An empirical study" International Journal of Multidisciplinary Research (Published by the Postgraduate School, Olabisi Onabanjo University, Ago-Iwoye, Ogun State, Nigeria) Vol. 1, No. 1. pp. 1-12

[14] Asiyanbola R. A. and Filani M. O. (2007) "Perception and involvement of women

[15] in housing development in Nigeria" Journal of Environment and Culture (Published by the Department of Archaeology and Anthropology, University of Ibadan, Ibadan, Nigeria) Vol. 4, Number 2, pp. 1-22

[16] Asiyanbola R. A. (1997) "Housing Studies and gender Issues: A Review of literature" In Bayo Amole (ed). The House in Nigeria history Place, environment and development Proceedings of a National symposium $23^{\text {rd }}-24^{\text {th }}$ July held at the Conference Centre, Obafemi Awolowo University, Ile Ife pp. 89 - 92.

[17] Aweda A. David (1984) "Sex-Role Inequalities in the African Family: Contemporary Implications". Ife Social Sciences Review Vol. 7, No. 1 \& 2 pp. 188-197.

[18] Ayeni B. (1994) "The metropolitan area of Ibadan its growth and structure" in Filan M. O.; Akintola F. O.; and Ikporukpo C. O. (eds.) Ibadan Region Rex Charles Publication Ibadan, pp. 72-84.

[19] Ayeni B. (1982) Map of Land-use Patterns in Ibadan, Unpublished cited in Abumere S. I. (1994) "Residential differentiation in Ibadan: Some sketches of an explanation" in Filan M. O.; Akintola F. O.; and Ikporukpo C. O. (eds.) Ibadan Region Rex Charles Publication Ibadan, pp. 72-84

[20] Bernard Jessie (1981) "The Good-Provider Role: Its Rise and Fall” American Psychologist, Vol. 36, No. 1, pp. 1-12.

[21] Carrigan Tim, Connell Bob, and Lee, John (1987) "The 'Sex-Role' Framework and the Sociology of Masculinity" in Weiner Gaby and Arnut, Madeleine (eds.) Gender Under Scrutiny: New Inquiries in Education. London: Hutchinson.

[22] Cater, J. and Trevor, J. (1989) Social Geography, London: Edward Arnold

[23] Filani, M.O.; Akintola, F.O. and Ikporukpo, C.O. (eds.) (1994) Ibadan Region, Rex Charles, Ibadan, Nigeria.

[24] Fishbein, m. and I. Ajzen (1975) Belief, attitude, intention and behaviour: An introduction to theory and research. Addison-Wesley Publishing Company: Reading, Massachusetts; pp. 336.

[25] Hartshorn, A. Truman (1992) Interpreting the city: An Urban Geography. John Wiley, New York.

[26] Hayden, D. and Wright G. (1976) "Architecture and Urban Planning" Signs 1, 923:933.

[27] Humm, M. (1989) The Dictionary of Feminist Theory. Harvester Wheatsheaf, London.Johnston, R.J. (1998) Geography and Geographers: Anglo-American Human Geography Since 1945. Edward Arnold: London.

[28] Knox Paul (1992) Urban Social Geography: An Introduction, Longman \& John Wiley, New York. Kramarae Cheris, (1992) "The Condition of Patriarchy". In Kramarae C. and Spender D. (eds.) The Knowledge Explosion: Generations of Feminist Scholarship. Athene Series, Teachers College Press, London, pp. 397-405

[29] Lerner G. (1986) The Creation of Patriarchy. Oxford University Press, Oxford. Mabogunje, A. (1962) "The Growth of Residential Districts in Ibadan". The Geographical Review, 52(1), 56-77.

[30] Mabogunje, A. L. (1968) Urbanization in Nigeria, London University Press, London, pp. 186-237.

[31] Merlo Rosangela and McDonald (2002) Outcomes of home-ownership aspirations and their determinants. Australian National University Research Centre, Australian Housing and Urban Research Institute.

[32] Moser C, O.N (1992) "Housing" in Ostrgaard Lise (ed.) Gender and Development: a Practical Guide. Routledge, London, pp. 7693.

[33] Moser Caroline O.N. (1993) Gender, Planning and Development: Theory, Practice and Training, Routledge, London.

[34] NISER, (1988) Socio-Economic Survey of Ibadan City Report of a Survey Commission by the Ibadan Metropolitan Planning Authority (IMPA), NISER, Ibadan.Olatubara C. O. (2003) "The participation of women in residential location decision-making in Ibadan, Nigeria" Journal of the NITP, Vol. XVI, No. 1, October, pp.19-33

[35] Onibokun 'Poju (1983) Issues in Nigeria Housing, NISER, Ibadan, pp. 45-65.

[36] Onibokun, G.A. (ed.) (1985) Housing in Nigeria: (A Book of Readings), NISER, Ibadan, pp. 65-83.

[37] Peterson Rebecca: Wekerle Gerda, R. and Morley David (1978) "Women and Environments: An Overview of an Emerging Field". Environment and Behaviour, vol. 10, No. 4, p. 511-534.

[38] Short, J. P. (1996) The Urban Order: An Introduction to Cities, Culture and Power. Blackwell, U.S.A.

[39] Silberschmidt Margrethe (1999) Women Forget that Men are the Masters" Gender Antagonism and socio-economic change in Kisii District, Kenya. Nordiska Afrikairstitutet, Sweden.

[40] Stacey, Jackie (1993) “Untangling Feminist theory" In: Richardson D, Robinson, V. (eds.) Introducing Women's Studies: Feminist Theory and Practice. Macmillian London, pp. 49-73.

[41] Stock Robert (1995) Africa South of the Sahara: a Geographical Interpretation. Guilford Press New York.

[42] UNCHS (1996) An Urbanizing World: Global Report on Human Settlements, United Nations Centre for Human Settlements (HABITAT) Oxford University Press.

[43] Woods Robertsa (1994) 'Introduction’ In Gilroy Rose and Woods Roberta (eds.) Housing women, Routledge, London.

[44] Young Kate (1995) Planning Development with women: Making a World of Difference. Macmillan, London. 